\author{
"WPISANIE" ORGANÓW ROZSTRZYGAJĄCYCH Z ZAKRESU \\ MIĘDZYNARODOWEGO PRAWA PRAW CZŁOWIEKA \\ W SYSTEM PRAWA MIĘDZYNARODOWEGO - ROZWAŻANIA \\ W KONTEKŚCIE HUMANIZACJI PRAWA MIĘDZYNARODOWEGO \\ I INTERNACJONALIZACJI PRAW CZŁOWIEKA
}

\title{
Wstęp
}

Wieloaspektowo postrzegana problematyka sądownictwa międzynarodowego jest jednym $\mathrm{z}$ tych zagadnień, którego renesans $\mathrm{w}$ ostatnich dziesięcioleciach minionego wieku wywarł znaczący i trwały wpływ na rozwój prawa międzynarodowego jako takiego. Będąca tego pochodną mnogość problemów badawczych i ich oddziaływanie na międzynarodową rzeczywistość, a także potrzeba mierzenia się z ową rzeczywistością na naukowym gruncie to szczególne wyzwania.

Analizując dorobek naukowy dr K. Stasiak, nie można mieć wątpliwości, że - wyznaczając wiodący obszar swojego naukowego zainteresowania - mierzyła się Ona z szeroko nakreśloną problematyką sądownictwa międzynarodowego. W licznych opracowaniach temu poświęconych poruszała zagadnienia zawiłych, teoretycznych uwarunkowań funkcjonowania współczesnego sądownictwa międzynarodowego, dając asumpt konstruktom myślowym, kierunkującym uwagę na społecznie doniosłe, praktyczne aspekty tego zagadnienia. Swoje badania naukowe dedykowała zarówno systemowi sądownictwa międzynarodowego in genere, jak i poszczególnym sądom czy szerzej - organom rozstrzygającym

* Dr hab., prof. US, dyrektor Instytutu Nauk Prawnych Uniwersytetu Szczecińskiego, e-mail: ewelina.cala-wacinkiewicz@usz.edu.pl, https:/ / orcid.org/000-0002-5439-4653. 
składającym się na ten system. Nie abstrahowała tym samym od zagadnień silnie zakotwiczonych doktrynalnie (takich jak np. sądownictwo międzynarodowe w systemie prawa międzynarodowego), jak i od wymagających specjalistycznej wiedzy studiów przypadków (np. rozważania poświęcone Specjalnemu Trybunałowi dla Republiki Środkowoafrykańskiej) ${ }^{1}$.

Mając powyższe na uwadze, niniejsze opracowanie - wpisując się w przedmiotowy zakres badań dr K. Stasiak - jest nie tylko próbą ukazania sposobu postrzegania ogólnego prawa międzynarodowego (general international law) ${ }^{2}$ przez pryzmat organów rozstrzygających z zakresu międzynarodowego prawa praw człowieka, ale nade wszystko oddaniem naukowego hołdu Koleżance, która odchodząc przedwcześnie, pozostawiła wiele pustych stron, w tym tych niezapisanych naukowymi przemyśleniami.

1 Wśród ważniejszych publikacji warto przywołać: K. Stasiak, Trybunaty umiędzynarodowione w systemie międzynarodowego sadownictwa karnego, Lublin 2012, s. 324; K. Stasiak, The Position of Defence Counsel before the International Criminal Court - a Few Comments on the Lubanga Case, The Review of Comparative Law 2012, t. 17, s. 85-108; K. Stasiak, Wspótpraca Organizacji Narodów Zjednoczonych z Prokuratorem Międzynarodowego Trybunału Karnego, w: Prawo organizacji międzynarodowych wobec problemów wspótczesnego świata. Księga pamiątkowa dedykowana Pani Profesor Genowefie Grabowskiej, red. B. Mikołajczyk, J. Nowakowska-Małusecka, Bydgoszcz-Katowice 2014, s. 323-333; K. Stasiak, Zasady dotyczace naprawienia szkody pokrzywdzonym w postępowaniu przed Międzynarodowym Trybunatem Karnym - uwagi dotyczace sprawy Thomasa Lubangi Dyilo, w: Międzynarodowe i europejskie prawo karne - osiągnięcia, kierunki rozwoju, wyzwania, red. J. Nowakowska-Małusecka, I. Topa, Katowice 2015, s. 152-74; K. Stasiak, Wewnętrzny system sprawiedliwości ONZ i jego doświadczenia w funkcjonowaniu po reformie 2009 r., w: System Narodów Zjednoczonych z polskiej perspektywy, red. E. Cała-Wacinkiewicz, J. Menkes, J. Nowakowska-Małusecka, A. Przyborodowska-Klimczak, W.Z. Staszewski, Warszawa 2017, s. 223-233; K. Stasiak, Specjalny Trybunat dla Republiki Środkowoafrykańskiej - nowy typ trybunatów umiędzynarodowionych?, w: Prawo międzynarodowe - idee a rzeczywistość, red. E. Cała-Wacinkiewicz, Warszawa 2018, s. 409-419.

2 W niniejszych rozważaniach celowo pomija się dystynkcje językowe pomiędzy pojęciami ogólnego prawa międzynarodowego (general international law), a powszechnego prawa międzynarodowego (universal international law), traktując pierwsze z nich jako wyodrębniane ze względu na kryteria przedmiotowe (merytoryczne), drugie zaś oparte na kryteriach podmiotowych. 


\section{Założenia badawcze}

Celem niniejszego opracowania jest ukazanie, że wpisanie w ogólne prawo międzynarodowe organów rozstrzygających z zakresu międzynarodowego prawa praw człowieka jest na tyle silne, że czyni naukowo koniecznym odrzucenie konstatacji Międzynarodowego Trybunału Karnego dla byłej Jugosławii, zgodnie z którą w prawie międzynarodowym każdy trybunał stanowi self-contained system ${ }^{3}$, jako argumentu przemawiającego na rzecz pełnej autonomii (niezależności) organów sądowych. Przeprowadzenie dowodu wskazującego na zasadność tak sformułowanej tezy badawczej musi opierać się na przesłankach dwojakiego rodzaju. Po pierwsze, termin „wpisanie”, choć posiada dość ogólny kontekst znaczeniowy, ma ten semantyczny walor, że wymusza potrzebę prowadzenia badań ukazujących, na ile organy rozstrzygające z zakresu międzynarodowego prawa praw człowieka w swojej orzeczniczej działalności sięgają do kategorii ogólnego prawa międzynarodowego ${ }^{4}$. Jest to o tyle istotne, że wspomniana kategoria stanowi swoiste spoiwo poszczególnych zbiorów norm prawnych w jedną całość (część wspólną prawa międzynarodowego) ${ }^{5}$. Po drugie, prowadzone badania zawężone zostaną do analizy orzecznictwa Europejskiego Trybunału Praw Człowieka (dalej: ETPC), wpisującego się - ze względu na swój status - w zakres pojęcia organu rozstrzygającego. Na zakres ten składają się bowiem zarówno sądy, trybunały, jak i inne organy lub ciała, których zadaniem jest rozstrzyganie sporów międzynarodowych zgodnie z prawem międzynarodowym.

Powyższe ustalenie nie stanowi jednak celu samego w sobie. Antycypowane wpisanie organów rozstrzygających z zakresu międzynarodowego

3 The Prosecutor v. Dusko Tadic, (Case No. IT-94-1-AR72), The Decision of the Appeals Chamber of the International Criminal Tribunal for the former Yugoslavia on the Defence Motion for Interlocutory Appeal on Jurisdiction of 2 October 1995, s. 11, http:/ / www.icty. org/case/tadic/4 [dostęp: 10.01.2020 r.].

4 Niniejsze rozważania stanowią formę sprowadzenia na grunt konkretnego przypadku (orzecznictwo ETPC) teoretycznych twierdzeń,poświęconych statusowi organów rozstrzygających jako takich, zawartych w opracowaniu E. Cała-Wacinkiewicz, Fragmentacja prawa międzynarodowego, Warszawa 2019.

5 Nieco inaczej ujmuje to C. Mik, traktując general international law jako zbiór reguł ogólnych prawa międzynarodowego, mających zastosowanie do różnych działów tego prawa. Zob. C. Mik, Lex generalis w prawie międzynarodowym, w: Ubi Ius Ibi Remedium. Księga dedykowana pamięci Profesora Jana Kolasy, red. B. Krzan, Warszawa 2016, s. 420. 
prawa praw człowieka w prawo międzynarodowe umożliwi udowodnienie istnienia wpływu (oddziaływania) humanizacji prawa międzynarodowego na międzynarodowy porządek prawny. Zwieńczeniem badań z tego zakresu będzie konfirmacja hipotezy badawczej, zgodnie z którą organy rozstrzygające z zakresu międzynarodowego prawa praw człowieka przyczyniają się nie tylko do humanizacji prawa międzynarodowego, lecz także do daleko idącej internacjonalizacji praw człowieka. Wprowadzenie owych dwóch kategorii (tj. humanizacji prawa międzynarodowego i internacjonalizacji praw człowieka) stanowi novum $\mathrm{w}$ dotychczas prowadzonych badaniach temu poświęconych, a weryfikacja tak postawionej hipotezy wyznacza zakres konstatacji realizowanych na podstawie metody analitycznej oraz metody formalno-dogmatycznej.

\section{Wpisanie Europejskiego Trybunału Praw Człowieka w system prawa międzynarodowego}

Analiza dorobku orzeczniczego ETPC, w kontekście odniesień do kategorii ogólnego prawa międzynarodowego, pozwala na sformułowanie pewnych uogólnień, celem egzemplifikacji twierdzenia o wpisaniu organów rozstrzygających z zakresu międzynarodowego prawa praw człowie$\mathrm{ka} \mathrm{w}$ system prawa międzynarodowego ${ }^{6}$. Do zbiorczej kategorii general international law - bazując na opracowanym zestawieniu statystycznym Trybunał odniósł się w 115 wyrokach ${ }^{7}$, explicite zawierających w swej treści

6 Zaznaczyć trzeba, że w niniejszym opracowaniu nie będzie dowodzona kwestia systemowości prawa międzynarodowego. Na ten temat zob. E. Cała-Wacinkiewicz, Fragmentacja prawa międzynarodowego..., W także J. Menkes, Nauka prawa międzynarodowego wobec wyzwań ery postwestfalskiej, w: Nauka prawa międzynarodowego u progu XXI wieku. Materiały pokonferencyjne, red. E. Dynia, Rzeszów 2003, s. 177; W. Czapliński, A. Wyrozumska, Prawo międzynarodowe publiczne, wyd. 3, Warszawa 2014, s. 11; Д. Флек, Международное право между фрагментацией и интеграиией: вызовы для теории и практики, Российский Юридический Журнал 2011, t. 81, z. 6, s. 7; L. Incisa di Camerana, Frammentazione e integrazione nel sistema internazionale, Politica Internazionale 1994, t. 22, nr 4, s. 81-106, a także D.J. Bederman, który ujmuje to słowami: „public international law is its own legal system with unique ways of making and enforcing rules". D.J. Bederman, The Spirit of International Law, Athens-London 2002, s. 1.

7 Statystykę zaprezentowano, opierając się na wyszukiwarce HUDOC, https://hudoc.echr.coe.int [dostęp: 10.01.2020 r.]. 
analizowaną kategorię. I choć wspomniane zestawienie nie może być uznane za w pełni wiarygodne źródło informacji na temat całościowej liczby takich odniesień (choćby ze względu na to, że pominięto w nim konkretne (poszczególne) instytucje, tworzące ogólne prawo międzynarodowe), to umożliwia nakreślenie pewnej tendencji pozwalającej stwierdzić, że liczba odesłań jest znaczna, a ich merytoryczne uwarunkowania i osadzenie w międzynarodowym kontekście zróżnicowane przedmiotowo.

Pierwszą grupę analizowanych wyroków ETPC stanowią te, w których Trybunał - odnosząc się do general international law - nawiązał do norm peremptoryjnych ius cogens ${ }^{8}$. Ze względu na swoją normatywną istotę normy te są traktowane jako nie tylko "the «higher law» prevailing over all other rules of the international law system" ${ }^{\prime 9}$, lecz także - jak ujmuje to C. Mik - działają one jak klauzula porządku publicznego, stanowiąca fundament cywilizowanego międzynarodowego porządku prawnego. Co warte podkreślenia, klauzula ta powoduje usuwanie z zakresu prawa międzynarodowego sprzecznych z nim zachowań sformalizowanych i ich następstw prawnych, w pewnym stopniu korygując także postępowanie podmiotów prawa międzynarodowego ${ }^{10}$.

Analizując charakter norm peremptoryjnych, Trybunał - w jednym z orzeczeń - traktując ius cogens jako rdzeń prawa międzynarodowego, odmówił nadania takiego charakteru m.in. normom wyinterpretowanym z przepisu art. 14 Międzynarodowego Paktu Praw Politycznych i Obywatelskich, podpisanego w Nowym Jorku dnia 19 grudnia 1966 r. $^{11}$, oraz tym zawartym w art. 6 Europejskiej konwencji o ochronie praw człowieka i podstawowych wolności, podpisanej w Rzymie dnia 4 listopada 1950 r. $^{12}$, traktującym o prawie do rzetelnego procesu. U podstaw stanowiska

8 Na temat przedmiotowych norm zob. szerzej: Ch.Z. Rozakis, The Concept of Ius Cogens in the Law of Treaties, Amsterdam-New York-Oxford 1976; L.M. Caplan, State Immunity, Human Rights, and Jus Cogens: A Critique of the Normative Hierarchy Theory, The American Journal of International Law 2003, t. 97, nr 4, s. 741-781; W. Czapliński, Ius cogens and the Law of Treaties, w: The Fundamental Rules of the International Legal Order. Jus Cogens and Obligations Erga Omnes, red. Ch. Tomuschat, J.-M. Thouvenin, Leiden-Boston 2006.

9 Takie ujęcie zob. R. Michaels, J. Pauwelyn, Conflict of Norms or Conflict of Laws?: Different Techniques in the Fragmentation of International Law, Duke Journal of Comparative and International Law 2012, t. 22, s. 364.

10 C. Mik, Ius cogens we wspótczesnym prawie międzynarodowym, w: Aksjologia wspótczesnego prawa międzynarodowego, red. A. Wnukiewicz-Kozłowska, Wrocław 2011, s. 276.

11 Dz. U. z 1977 r. Nr 38, poz. 167, załącznik.

12 Dalej: Europejska konwencja, Dz. U. z 1993 r. Nr 61, poz. 284 z późn. zm., załącznik. 
Trybunału legły kontrowersje dotyczące możliwości nadania statusu ius cogens normom o charakterze regionalnym. Trybunał przywołując stanowisko Komisji Prawa Międzynarodowego, zważył, że

various tribunals, national and international, have affirmed the idea of peremptory norms in contexts not limited to the validity of treaties. Those peremptory norms that are clearly accepted and recognised include the prohibitions of aggression, genocide, slavery, racial discrimination, crimes against humanity and torture, and the right to self-determination ${ }^{13}$.

Przedmiotowe spostrzeżenie Trybunału, nawiązujące w swej istocie do powszechnie akceptowalnego katalogu norm ius cogens, potwierdza zasadność twierdzenia, że bez nawiązywania do dorobku ogólnego prawa międzynarodowego i czerpania z klasycznych instytucji nie będzie możliwe ustalenie statusu, a nawet - idąc dalej - także treści norm prawnych z zakresu międzynarodowego prawa praw człowieka. Potwierdzenie przedmiotowego spostrzeżenia odnaleźć można w stanowisku sędziów P. Pinto de Albuquerquéa oraz D. Dedova, którzy - na bazie postanowień art. 6 Europejskiej konwencji - odnotowali, że sam fakt istnienia w ogólnym prawie międzynarodowym określonych zasad (nawet jeśli nie kwalifikować ich jako ogólnych zasad prawa uznanych przez narody cywilizowane) zwalnia z obowiązku szczegółowego analizowania ich znaczenia oraz z oceny statusu zasad prawa na gruncie międzynarodowego prawa praw człowieka ${ }^{14}$. W oparciu o to stanowisko daje się wywieść uniwersalny charakter general international law, implikujący możliwość stosowania w poszczególnych działach prawa międzynarodowego instytucji prawnych, składających się na ogólne prawo międzynarodowe. Nie oznacza to tym samym, że w poszczególnych działach prawa międzynarodowego a priori wyklucza się możliwość dostosowania określonej instytucji do potrzeb tego działu, z uwzględnieniem normatywnej specyfiki tego ostatniego. Wręcz przeciwnie. Przykładu w tym zakresie - w odniesieniu do zasad odpowiedzialności państw, przewidzianych ogólnym prawem międzynarodowym - dostarcza chociażby inaczej uregulowany

13 Case of Al-Dulimi and Montana Management Inc. v. Switzerland, Application No. 5809/08, The Judgment of the European Court of Human Rights of 21 June 2016.

14 Joint Concurring Opinion of Judges Paulo Pinto de Albuquerque and Dmitry Dedov, Case of Baka v. Hungary, Application No. 20261/12, The Judgment of the European Court of Human Rights of 23 June 2016. 
tryb odpowiedzialności państw oparty na postanowieniach Europejskiej konwencji czy - sięgając do przykładu spoza obszaru praw człowieka bardziej rygorystyczny tryb odpowiedzialności państw za działalność prowadzoną w kosmosie.

Nawiązując do powyższego, przegląd orzecznictwa ETPC dostarcza przykładów na to, że kwestia odpowiedzialności państw jest problematyką dość często poruszaną na gruncie orzecznictwa Trybunału. Dowodzi tego odnoszenie się do odpowiedzialności państwa za działanie niezgodne z prawem międzynarodowym, co - w opinii Trybunału - winno każdorazowo następować w kontekście i na podstawie ogólnego prawa międzynarodowego ${ }^{15}$.

Kolejnym przykładem wpisania ETPC w system prawa międzynarodowego jest posługiwanie się kategorią general international law w opisie relacji między prawem krajowym a prawem międzynarodowym. Co ciekawe, w swoim orzecznictwie Trybunał położył nacisk nie tylko na powiązania między prawem krajowym a ogólnymi zasadami prawa międzynarodowego lub umowami międzynarodowymi ${ }^{16}$, z dwoma ostatnimi utożsamiając ogólne prawo międzynarodowe, ale idąc dalej, uwypuklił nadaną sądom krajowym kompetencję do interpretowania i stosowania ustawodawstwa krajowego, zgodnie z zasadami ogólnego prawa międzynarodowego i postanowieniami umów międzynarodowych ${ }^{17}$. I choć problematyka prawa krajowego pozostaje poza zakresem niniejszych analiz, to

15 Case of Jaloud v. The Netherlands, Application No. 47708/08, The Judgment of the European Court of Human Rights of 20 November 2014; Case of Chiragov and Others v. Armenia, Application No. 13216/05, The Judgment of the European Court of Human Rights of 16 June 2015; Case of Mamatkulov and Askarov v. Turkey, Applications Nos. 46827/99 and 46951/99, The Judgment of the European Court of Human Rights of 4 February 2005.

16 Case of Waite and Kennedy v. Germany, Application No. 26083/94, The Judgment of the European Court of Human Rights of 18 February 1999; Case of Korbely v. Hungary, Application No. 9174/02, The Judgment of the European Court of Human Rights of 19 September 2008; Case of Markovic and Others v. Italy, Application No. 1398/03, The Judgment of the European Court of Human Rights of 14 December 2006; Case of Prince Hans-Adam II of Liechtenstein v. Germany, Application No. 42527/98, The Judgment of the European Court of Human Rights of 12 July 2001; Case of Molla Sali v. Greece, Application No. 20452/14, The Judgment of the European Court of Human Rights of 19 December 2018.

17 Case of X v. Latvia, Application No. 27853/09, The Judgment of the European Court of Human Rights of 26 November 2013. 
zwrócenie uwagi na możliwość wykorzystania poszczególnych instytucji ogólnego prawa międzynarodowego także na gruncie prawa krajowego nie może zostać przemilczana.

Co warte odnotowania, odesłanie do zasad general international law postanowień umów międzynarodowych czy innych przepisów prawa daje się także wywieść z orzeczeń ETPC podejmujących tematykę immunitetu jurysdykcyjnego ${ }^{18}$ czy sukcesji państw ${ }^{19}$. Bez wątpienia instytucje te stanowią rdzeń prawa międzynarodowego, będąc immanentnie sprzężonymi z tym porządkiem prawnym.

Kolejnym obszarem ogólnego prawa międzynarodowego, do którego w różnych kontekstach na gruncie swojego orzecznictwa odnosi się ETPC, są kwestie dotyczące ekstradycji oraz ustalanej na podstawie ogólnego prawa międzynarodowego odpowiedzialności państwa przyjmują$\operatorname{cego}^{20}$. W tym ujęciu Trybunał przywołuje zarówno zasady prawa międzynarodowego, jak i konwencje czy inne źródła dopuszczone na gruncie tego prawa. Mimo tego, że ostatni z wymienionych aspektów ma dość enigmatyczny charakter, to nie budzi wątpliwości, iż pozostawienie luzu interpretacyjnego służyć może promiędzynarodowej wykładni prawa dokonywanej przez sądy krajowe. Należy bowiem pamiętać, że mająca dualny charakter ekstradycja jest instytucją zarówno prawa krajowego, jak i prawa międzynarodowego ${ }^{21}$.

Podobne ustalenia, choć nawiązujące w szerszym zakresie do ogólnego prawa międzynarodowego, odnaleźć można w kolejnym orzeczeniu ETPC, zapadłym na kanwie problematyki wzajemnej pomocy prawnej państw w sprawach karnych. Trybunał przywołując obowiązek

18 Case of Waite and Kennedy v. Germany, Application No. 26083/94, The Judgment of the European Court of Human Rights of 18 February 1999. Na temat immunitetu zob. szerzej: J. Menkes, Immunitet jurysdykcyjny organizacji międzynarodowej - immunitet jurysdykcyjny państwa: zwrot wektorów, w: Ewolucja immunitetów mających swoje źródło w prawie międzynarodowym, red. I. Skomerska-Muchowska, Łódź 2014.

19 Case of Andrejeva v. Latvia, Application No. 55707/00, The Judgment of The European Court of Human Rights of 18 February 2009; Case of Ališić and Others v. Bosnia and Herzegovina, Croatia, Serbia, Slovenia and The Former Yugoslav Republic Of Macedonia, Application No. 60642/08, The Judgment of The European Court of Human Rights of 16 July 2014.

20 Case of Mamatkulov and Askarov v. Turkey, Applications Nos. 46827/99 and 46951/99, The Judgment of the European Court of Human Rights of 4 February 2005.

21 Z. Knypl, Ekstradycja jako instytucja prawa międzynarodowego i wewnętrznego, Warszawa 1975. 
współpracy pomiędzy państwami, wymagał wyczerpania w dobrej wierze wszystkich dostępnych państwom możliwości, wynikających z obowiązujących instrumentów międzynarodowych czy ponadnarodowych lub z ogólnego prawa międzynarodowego ${ }^{22}$.

Ostatnim przykładem obrazującym wpisanie organów rozstrzygających z zakresu międzynarodowego prawa praw człowieka w system prawa międzynarodowego jest osadzenie prawa ofiar tortur do uzyskania zadośćuczynienia oraz do sprawiedliwego i odpowiedniego odszkodowania w ogólnym prawie międzynarodowym ${ }^{23}$. Podobne podejście Trybunał zastosował także na kanwie przepisów dotyczących karania zbrodni wojennych i zbrodni przeciwko ludzkości. Uznał, że ze względu na fakt, iż zbrodnie te zagrażają fundamentom ludzkości i międzynarodowemu współistnieniu, stanowią reguły ogólnego prawa międzynarodowego ${ }^{24}$.

Podsumowując powyższy przegląd orzecznictwa ETPC, warto wskazać, mimo pewnej oczywistości tego spostrzeżenia, że Trybunał działając na podstawie umowy międzynarodowej, tj. Europejskiej konwencji, związany jest prawem międzynarodowym. Co ciekawe, takie stanowisko potwierdza on także swoim orzecznictwem, wprost uznając, że

the Convention cannot be interpreted in a vacuum. The Court must be mindful of the Convention's special character as a human rights treaty, and it must also take the relevant rules of international law into account. The Convention should so far as possible be interpreted in harmony with other rules of international law of which it forms part ${ }^{25}$.

Łącząc bogate orzecznictwo Trybunału, odwołujące się wprost do ogólnego prawa międzynarodowego, z wyrazistym twierdzeniem umiejscawiającym Europejską konwencję w systemie prawa międzynarodowego, za dowiedziony uznać należy fakt wpisania organów rozstrzygających

22 Case of Güzelyurtlu and Others v. Cyprus and Turkey, Application No. 36925/07, The Judgment of the European Court of Human Rights of 29 January 2019.

23 Case of Naït-Liman v. Switzerland, Application No. 51357/07, The Judgment of The European Court of Human Rights of 15 March 2018.

24 Case of Korbely v. Hungary, Application No. 9174/02, The Judgment of the European Court of Human Rights of 19 September 2008.

25 Case of McElhinney v. Ireland, Application No. 31253/96, The Judgment of the European Court of Human Rights of 21 November 2001, pkt 36, a także przywołany wyżej Case of Al-Adsani v. The United Kingdom, Application No. 35763/97, The Judgment of the European Court of Human Rights of 21 November 2001, pkt 55. 
z zakresu międzynarodowego prawa praw człowieka w system prawa międzynarodowego. Tym samym przywołana na wstępie konstatacja Międzynarodowego Trybunału Karnego dla byłej Jugosławii, zgodnie z którą w prawie międzynarodowym każdy trybunał stanowi self-contained system, nie może być interpretowana jako argument na rzecz odcięcia organów rozstrzygających od ogólnego prawa międzynarodowego. Ich autonomia winna być rozumiana $\mathrm{w}$ znaczeniu funkcjonalnym, nie zaś utożsamiana z pełną niezależnością tych organów względem general international law.

\section{Humanizacja prawa międzynarodowego czy internacjonalizacja praw człowieka?}

Oddziaływanie organów rozstrzygających (w tym tych z zakresu międzynarodowego prawa praw człowieka) na międzynarodowy system prawny $^{26}$ jest bezsprzeczne. Jest bowiem faktem, że proliferacja prawnomiędzynarodowego sądownictwa, jak widzi to A. Kozłowski, odciska swoje piętno na procesie rozwoju prawa międzynarodowego ${ }^{27}$. Czy jednak ocena owego oddziaływania jedynie przez pryzmat wpływu praw człowieka na system prawa międzynarodowego (wyprzedzająco - humanizacja prawa międzynarodowego) nie stanowi nieuprawnionego zawężenia analiz? Czy biorąc za podstawę wspomniane zjawisko humanizacji tego prawa, nie należałoby jednocześnie rozważyć wpływu międzynarodowego porządku prawnego na prawa człowieka, ujmując go w ramy internacjonalizacji praw człowieka? Postawienie przedmiotowych pytań in extenso nawiązuje do sformułowanej na wstępie hipotezy badawczej, zgodnie z którą organy rozstrzygające z zakresu międzynarodowego prawa praw człowieka przyczyniają się nie tylko do humanizacji prawa międzynarodowego, lecz także do daleko idącej internacjonalizacji praw człowieka.

${ }^{26}$ Na ten temat zob. szerzej: J.I. Charney, The Impact on the International Legal System of the Growth of International Courts and Tribunals, New York University Journal of International Law and Politics 1999, t. 31, nr 4, s. 697.

27 A. Kozłowski, Wpływ sądownictwa międzynarodowego na rozwój prawa międzynarodowego, w: Wspótczesne sądownictwo międzynarodowe, t. 1: Wybrane zagadnienia prawne, red. J. Kolasa, Wrocław 2010, s. 52. 
Zagadnienie humanizacji prawa międzynarodowego mimo tego, że nie doczekało się rozbudowanych ilościowo analiz doktrynalnych, podjęte zostało w cieniu badań nad general international law i rolą, jaką odgrywają w nim prawa człowieka ${ }^{28}$. Wskazują na to opracowania B. Simmy ${ }^{29}$, T. Merona ${ }^{30}$ czy A.A. Cançado Trindade ${ }^{31}$, a łącząca je wspólna intuicja badawcza, sformułowana przez T. Merona, explicite wskazuje, że to właśnie dotyczące praw człowieka normy i instytucje spowodowały rewolucję w systemie prawa międzynarodowego, promieniując na inne działy ${ }^{32}$ i konfirmując twierdzenie, że "human rights law is part and parcel of the general law"33. Jeśliby ową intuicję uzupełnić o zauważalne sprzężenie zwrotne, dotyczące oddziaływania prawa międzynarodowego na prawa człowieka, do czego uprawnia także dokonany przegląd orzecznictwa ETPC, to wniosek o istnieniu pewnej obustronnej implikacji rzeczonych kategorii wart będzie szczególnej uwagi.

Prezentowanie praw człowieka w ramach koncepcji humanizacji prawa międzynarodowego ma bez wątpienia szczególne znaczenie. Prawa człowieka nie tylko stanowią źródło jedności systemu prawa międzynarodowego, ale będąc kwalifikowane jako część general international law, potwierdzają systemowość tego prawa. W tym ujęciu w humanizacji prawa międzynarodowego, będącej w swej istocie procesem, stanem

28 The Impact of Human Rights Law on General International Law, red. M. Kamminga, M. Shenin, Oxford 2009, A.N. Pronto, 'Human-Rightism' and the Development of General International Law, Leiden Journal of International Law 2007 (special edition: Essays in Honour of Prof. John Dugard), t. 20, z. 4, s. 753-765.

29 B. Simma, International Human Rights and General International Law: A Comparative Analysis, Collected Courses of the Academy of European Law (Yearbook) 1993, t. 4, ks. 2: The Protection of Human Rights in Europe, s. 153-236.

30 T. Meron, The Humanization of International Law, Leiden-Boston 2006, a także wcześniejsze opracowania: T. Meron, Human Rights and Humanitarian Norms as Customary Law, Oxford 1989; T. Meron, The Humanization of Humanitarian Law, American Journal of International Law 2000, t. 94, z. 2, s. 239-278.

31 Zob. Judge A.A. Cançado Trindade, The Construction of a Humanized International Law. A Collection of Individual Opinions (1991-2013), (preface by D. Spielmann, general introduction by A. Drzemczewski), Leiden-Boston 2014, a zwłaszcza rozdział poświęcony: The Humanization of International law, s. 99-196, A.A. Cançado Trindade, International Law for Humankind: Towards a New Jus Gentium. Second Revised Edition The Hague Academy of International Law Monographs, Leiden 2013.

32 T. Meron, The Humanization of International Law, Leiden-Boston 2006.

33 A.N. Pronto, 'Human-Rightism' ..., s. 764. 
i zjawiskiem, należy z jednej strony upatrywać takiego oddziaływania praw człowieka na system prawa międzynarodowego, które scala go w całość, z drugiej zaś, które zmierza do wprowadzenia do poszczególnych działów prawa międzynarodowego regulacji prawno-człowieczych, z uwzględnieniem jurydycznej natury tychże działów ${ }^{34}$. Tak pojmowana humanizacja prawa międzynarodowego uwidacznia się w kontekście wpisania ETPC w system prawa międzynarodowego. Trybunał - niejako na własny użytek - przywołując instytucje ogólnego prawa międzynarodowego, sytuuje się nie tylko jako instytucja działająca w obrębie międzynarodowego (europejskiego) prawa praw człowieka, lecz także jako instytucja związana prawem międzynarodowym.

Poprzestanie na wyprowadzeniu wniosku o humanizacji prawa międzynarodowego, jak powyżej sugerowano, stanowiłoby pewne nieuprawnione zawężenie analiz poświęconych wpisaniu organów rozstrzygających w system prawa międzynarodowego, stąd konieczne jest zwrócenie uwagi na - posiadającą wspólny mianownik z humanizacją prawa międzynarodowego - internacjonalizację praw człowieka. Przedmiotowa kategoria kierunkuje sposób myślenia na temat roli praw człowieka w systemie prawa międzynarodowego, opierając się na myśli M. Lachsa uwidaczniającej, że wśród powstających coraz to nowych rozdziałów prawa międzynarodowego, stanowiących refleks coraz ściślejszej współpracy w skali regionalnej i światowej, specjalną rolę $\mathrm{w}$ rozwoju prawa międzynarodowego odgrywają prawa człowieka ${ }^{35}$. Wątek praw człowieka w polskim i zagranicznym piśmiennictwie $\mathrm{z}$ tego zakresu pojawia się niebezpodstawnie.

Zachowując spójność z wcześniejszymi ustaleniami, internacjonalizacja praw człowieka, będąca w swej istocie procesem, stanem i zjawiskiem, może być - z jednej strony - postrzegana jako oddziaływanie ogólnego prawa międzynarodowego na prawa człowieka, które spaja system prawa międzynarodowego w całość (analogicznie do humanizacji prawa międzynarodowego). Z drugiej zaś - co w tym kontekście naukowo bardziej doniosłe - jako stanowiąca gwarant wewnętrznej spójności (niesprzeczności) systemu prawa międzynarodowego poprzez zapewnienie zgodności regulacji prawno-człowieczych (ich podporządkowanie) z ogólnym prawem

34 Szersze analizy poświęcone humanizacji prawa międzynarodowego prezentowane były w formie wirtualnej na The 35th International Business Information Management Conference (IBIMA Conference), 1-2 April 2020, Seville, Spain.

35 M. Lachs, Czy kryzys prawa międzynarodowego?, Państwo i Prawo 1992, nr 2, s. 18-24. 
międzynarodowym. Stanowiąc i stosując prawo międzynarodowe zarazem, przy jednoczesnym wykorzystywaniu powszechnie akceptowalnego dorobku general international law, osiąga się niejako a priori efekt jednolitości instytucjonalnej. Tym samym unika się (mając na uwadze pewien idealizm tego stwierdzenia) sprzeczności określonych instytucji prawnych (np. z zakresu międzynarodowego prawa praw człowieka) z general international law. Tak postrzegana internacjonalizacja praw człowieka, jak i internacjonalizacja każdego innego działu prawa międzynarodowego, będzie miała porządkujący - w wertykalnym układzie - charakter.

Międzynarodowe prawo praw człowieka nie ma normatywnie samodzielnego charakteru. Stanowiąc część większej całości, pozostaje w immanentnym związku z rdzeniem, jakim jest ogólne prawo międzynarodowe. Stąd tak istotne jest to, by rozwój regulacji prawnych w obrębie działów prawa międzynarodowego, będący tym samym rozwojem prawa międzynarodowego jako takiego, przebiegał harmonijnie i - poprzez internacjonalizację poszczególnych działów tworzących system prawa międzynarodowego - nie generował ich sprzeczności z ogólnym prawem międzynarodowym.

Pomiędzy kategoriami humanizacji prawa międzynarodowego a internacjonalizacji praw człowieka istnieje - w świetle prowadzonych analiz - szczególna relacja, sprowadzająca się nie tylko do współwystępowania owych kategorii, ale co więcej, do ich współzależności.

\section{Zakończenie}

W niniejszym opracowaniu odniesiono się do zagadnienia wpisania organów rozstrzygających z zakresu międzynarodowego prawa praw człowieka w system prawa międzynarodowego, wskazując na obustronną implikację zachodzącą pomiędzy oddziaływaniem praw człowieka na system prawa międzynarodowego i wzajemnie - oddziaływaniem instytucji ogólnego prawa międzynarodowego na prawa człowieka. Jak podkreśla J.I. Charney, ",one strength of the multiplicity of international tribunals is that it permits a degree of experimentation and exploration, which can lead to improvements in international law"36.

36 J.I. Charney, The impact..., s. 700. 
Rekapitulując, ustalenia zapadłe w toku badań uprawniają konfirmację postawionej na wstępie hipotezy badawczej, zgodnie z którą organy rozstrzygające z zakresu międzynarodowego prawa praw człowieka przyczyniają się nie tylko do humanizacji prawa międzynarodowego, lecz także do daleko idącej internacjonalizacji praw człowieka. To wzajemne odziaływanie - objęte współzależnością analizowanych kategorii - ma charakter wertykalny. Wspomniane organy, zwłaszcza te o wyspecjalizowanym charakterze, bezpośrednio - w ramach systemowych powiązań - odwołują się do ogólnego prawa międzynarodowego, nie zawężając swoich rozstrzygnięć jedynie do regulacji prawnych działu, w którym są osadzone.

Egzemplifikacje tego twierdzenia stanowi perspektywa badawcza łącznego postrzegania praw człowieka i organów rozstrzygających z zakresu międzynarodowego prawa praw człowieka, w zawężeniu do studium przypadku, za jaki obrano ETPC. To zaś skłania do konkluzji, antycypowanej we wprowadzeniu, że zagadnienie sądownictwa międzynarodowego jest jednym z tych, które nie tylko może, ale powinno być rozpatrywane wieloaspektowo. Owa wieloaspektowość daje zaś asumpt do ukazywania teoretycznych konstrukcji procesów, stanów i zjawisk, takich jak analizowane humanizacja prawa międzynarodowego i internacjonalizacja praw człowieka. Dostarcza także - jak sugerowano na wstępie mnogości problemów badawczych, oddziałujących na międzynarodową rzeczywistość. Już to stanowi wystarczający bodziec, by uświadomić sobie, dlaczego dr K. Stasiak zagadnieniu sądownictwa międzynarodowego poświęciła swoje naukowe konstatacje, czyniąc $\mathrm{z}$ tego zagadnienia nie tylko przedmiot badań, ale i życiową pasję.

\section{Bibliografia}

Bederman D.J., The Spirit of International Law, Athens-London 2002.

Cała-Wacinkiewicz E., Fragmentacja prawa międzynarodowego, Warszawa 2019.

Cançado Trindade A.A., International Law for Humankind: Towards a New Jus Gentium. Second Revised Edition The Hague Academy of International Law Monographs, Leiden 2013.

Cançado Trindade A.A., The Construction of a Humanized International Law. A Collection of Individual Opinions (1991-2013), (preface by D. Spielmann, general introduction by A. Drzemczewski), Leiden-Boston 2014. 
Caplan L.M., State Immunity, Human Rights, and Jus Cogens: A Critique of the Normative Hierarchy Theory, The American Journal of International Law 2003, t. 97, nr 4.

Charney J.I., The Impact on the International Legal System of the Growth of International Courts and Tribunals, New York University Journal of International Law and Politics 1999, t. 31, nr 4.

Czapliński W., Ius cogens and the Law of Treaties, w: The Fundamental Rules of the International Legal Order. Jus Cogens and Obligations Erga Omnes, red. Ch. Tomuschat, J.-M. Thouvenin, Leiden-Boston 2006.

Czapliński W., Wyrozumska A., Prawo międzynarodowe publiczne, wyd. 3, Warszawa 2014.

Incisa di Camerana L., Frammentazione e integrazione nel sistema internazionale, Politica Internazionale 1994, t. 22, nr 4.

Knypl Z., Ekstradycja jako instytucja prawa międzynarodowego i wewnętrznego, Warszawa 1975.

Kozłowski A., Wptyw sądownictwa międzynarodowego na rozwój prawa międzynarodowego, w: Wspótczesne sądownictwo międzynarodowe, t. 2: Wybrane zagadnienia prawne, red. J. Kolasa, Wrocław 2010.

Lachs M., Czy kryzys prawa międzynarodowego?, Państwo i Prawo 1992, nr 2.

Menkes J., Immunitet jurysdykcyjny organizacji międzynarodowej - immunitet jurysdykcyjny państwa: zwrot wektorów, w: Ewolucja immunitetów mających swoje źródto w prawie międzynarodowym, red. I. Skomerska-Muchowska, Łódź 2014.

Menkes J., Nauka prawa międzynarodowego wobec wyzwań ery postwestfalskiej, w: Nauka prawa międzynarodowego u progu XXI wieku. Materiaty pokonferencyjne, red. E. Dynia, Rzeszów 2003.

Meron T., Human Rights and Humanitarian Norms as Customary Law, Oxford 1989.

Meron T., The Humanization of Humanitarian Law, American Journal of International Law 2000, t. 94, z. 2.

Meron T., The Humanization of International Law, Leiden-Boston 2006.

Michaels R., Pauwelyn J., Conflict of Norms or Conflict of Laws?: Different Techniques in the Fragmentation of International Law, Duke Journal of Comparative and International Law 2012, t. 22.

Mik C., Lex generalis w prawie międzynarodowym, w: Ubi Ius Ibi Remedium. Księga dedykowana pamięci Profesora Jana Kolasy, red. B. Krzan, Warszawa 2016.

Pronto A.N., 'Human-Rightism' and the Development of General International Law, Leiden Journal of International Law 2007 (special edition: Essays in Honour of Prof. John Dugard), t. 20, z. 4.

Rozakis Ch.Z., The Concept of Ius Cogens in the Law of Treaties, Amsterdam-New York-Oxford 1976.

Simma B., International Human Rights and General International Law: A Comparative Analysis, Collected Courses of the Academy of European Law (Yearbook) 1993, t. 4, ks. 2: The Protection of Human Rights in Europe. 
Stasiak K., Trybunaty umiędzynarodowione w systemie międzynarodowego sądownictwa karnego, Lublin 2012.

Stasiak K., The Position of Defence Counsel before the International Criminal Court - a Few Comments on the Lubanga Case, The Review of Comparative Law 2012, t. 17.

Stasiak K., Wspótpraca Organizacji Narodów Zjednoczonych z Prokuratorem Międzynarodowego Trybunatu Karnego, w: Prawo organizacji międzynarodowych wobec problemów wspótczesnego świata. Księga pamiątkowa dedykowana Pani Profesor Genowefie Grabowskiej, red. B. Mikołajczyk, J. Nowakowska-Małusecka, Bydgoszcz-Katowice 2014.

Stasiak K., Zasady dotyczace naprawienia szkody pokrzywdzonym w postępowaniu przed Międzynarodowym Trybunatem Karnym - uwagi dotyczace sprawy Thomasa Lubangi Dyilo, w: Międzynarodowe i europejskie prawo karne - osiagnięcia, kierunki rozwoju, wyzwania, red. J. Nowakowska-Małusecka, I. Topa, Katowice 2015.

Stasiak K., Wewnętrzny system sprawiedliwości ONZ i jego doświadczenia w funkcjonowaniu po reformie 2009 r., w: System Narodów Zjednoczonych z polskiej perspektywy, red. E. Cała-Wacinkiewicz, J. Menkes, J. Nowakowska-Małusecka, A. Przyborodowska-Klimczak, W.Sz. Staszewski, Warszawa 2017.

Stasiak K., Specjalny Trybunat dla Republiki Środkowoafrykańskiej - nowy typ trybunatów umiędzynarodowionych?, w: Prawo międzynarodowe - idee a rzeczywistość, red. E. Cała-Wacinkiewicz, Warszawa 2018.

The Impact of Human Rights Law on General International Law, red. M. Kamminga, M. Shenin, Oxford 2009.

Флек Д., Международное право между фрагментаиией и интеграцией: вызовы для теории и практики, Российский Юридический Журнал 2011, t. 81, z. 6.

\section{Streszczenie}

Celem niniejszego opracowania jest ukazanie, że wpisanie $\mathrm{w}$ ogólne prawo międzynarodowe organów rozstrzygających z zakresu międzynarodowego prawa praw człowieka jest na tyle silne, iż czyni naukowo koniecznym odrzucenie twierdzeń przemawiających na rzecz pełnej autonomii (niezależności) organów sądowych w prawie międzynarodowym.

Powyższe ustalenie nie stanowi jednak celu samego w sobie. Antycypowane wpisanie organów rozstrzygających z zakresu międzynarodowego prawa praw człowieka w prawo międzynarodowe umożliwi udowodnienie istnienia wpływu (oddziaływania) humanizacji prawa międzynarodowego na międzynarodowy porządek prawny. Zwieńczeniem badań z tego zakresu jest konfirmacja hipotezy badawczej, zgodnie z którą organy rozstrzygające z zakresu międzynarodowego prawa praw człowieka przyczyniają się nie tylko do humanizacji prawa międzynarodowego, lecz także do daleko idącej internacjonalizacji praw człowieka. 
Wprowadzenie owych dwóch kategorii (tj. humanizacji prawa międzynarodowego i internacjonalizacji praw człowieka) stanowi novum w dotychczas prowadzonych badaniach temu poświęconych, a weryfikacja tak postawionej hipotezy wyznacza zakres konstatacji, realizowanych na podstawie metody analitycznej oraz metody formalno-dogmatycznej.

Słowa kluczowe: organy rozstrzygające, międzynarodowe prawo praw człowieka, Europejski Trybunał Praw Człowieka, humanizacja prawa międzynarodowego, internacjonalizacja praw człowieka

\section{"INSCRIBING" ADJUDICATING BODIES IN CASES INVOLVING INTERNATIONAL LAW OF HUMAN RIGHTS INTO THE SYSTEM OF INTERNATIONAL LAW - REFLECTIONS IN THE CONTEXT OF HUMANIZATION OF INTERNATIONAL LAW AND INTERNATIONALIZATION OF HUMAN RIGHTS}

\section{Summary}

The purpose of this study is to demonstrate that "inscribing" adjudicating bodies in cases involving international law of human rights into the universal international law is so strong, that it makes it scientifically necessary to reject assertions advocating full autonomy (independence) of judicial bodies in international law.

The above finding does not, however, constitute an end in itself. The anticipating inscription of adjudicating bodies of international law of human rights into international law will make it possible to prove the existence of the influence (impact) of humanization of international law over the international legal order. The culmination of research in this regard will involve confirmation of the research hypothesis according to which bodies adjudicating in cases involving international law of human rights contribute not only to humanization of international law, but also to far-reaching internationalization of human rights. Introduction of these categories (that is humanization of international law and internationalization of human rights) is a novum in current research addressing this subject matter and verification of the hypothesis outlines the scope of observations carried out on the basis of the analytical method and the method of interpretation of applicable law.

Key words: adjudicating bodies, international law of human rights, the European Court of Human Rights, humanization of international law, internationalization of human rights 


\section{«ВКЛЮЧЕНИЕ» РЕШАЮЩИХ ОРГАНОВ В ОБЛАСТИ МЕЖДУНАРОДНОГО ПРАВА ПРАВ ЧЕЛОВЕКА В СИСТЕМУ МЕЖДУНАРОДНОГО ПРАВА - РАССУЖДЕНИЯ В КОНТЕКСТЕ ГУМАНИЗАЦИИ МЕЖДУНАРОДНОГО ПРАВА И ИНТЕРНАЦИОНАЛИЗАЦИИ ПРАВ ЧЕЛОВЕКА}

\section{Резюме}

Цель данного исследования - показать, что «включение» органов, принимающих решения в области международного права прав человека в общее международное право настолько сильное, что необходимым, с научной точки зрения, является отклонение утверждений в пользу полной автономии (независимости) судебных органов в международном праве.

Однако вышеуказанный вывод не является самоцелью. Ожидаемое включение решающих органов в области международного права прав человека в международное право позволит доказать наличие воздействия гуманизации международного права на международно-правовой порядок. Завершением исследований в этой области является подтверждение исследовательской гипотезы, согласно которой судебные органы в области международного права прав человека способствуют не только гуманизации международного права, но и далеко идущей интернационализации прав человека. Введение этих двух категорий (т. е. гуманизации международного права и интернационализации прав человека) является поvит в исследованиях, посвященных до сих пор этим вопросам. Проверка данной гипотезы определяет объем выводов, сделанных на основе аналитического и формально-догматического методов.

Ключевые слова: решающие органы, международное право прав человека, Европейский суд по правам человека, гуманизация международного права, интернационализация прав человека 